\title{
Financieel management bij directe buitenlandse investeringen in Europa
}

\section{Patronen bij zeven Nederlandse investeerders}

\section{Wim Westerman}

SAMENVATTING Dit artikel gaat over het financieel management van Nederlandse ondernemingen bij Europese investeringen en de patronen die in de investeringsprocessen te herkennen zijn. Hiertoe zijn zowel de strategische analyse, de financiële investeringsselectie, de risico- en financieringsaspecten, als het organisatiegedrag geconceptualiseerd. Het resulterende model is vervolgens toegepast op zeven investeerders, waaronder vier beursgenoteerde: Numico, Randstad, Nutreco en Boskalis. Het gaat om in hun sector vooraanstaande investeerders, onder meer variërend qua groeistrategie (greenfields of overnames), omvang van de onderneming, omvang van de investeringen en wijze van ondernemingsbesturing. Bij het toetsen van een investering gaat het om de financiële waardecreatie. De wijze van internationalisering ligt voor het investeren al vrijwel vast. Meer of minder uitgewerkte strategische analyses geven de kaders voor de financiële waardering. Als financiële modellering uitgebreider en diverser wordt, verschuift het accent van boekhoudkundige naar contante waarde selectiemethoden. Financiële risico's doen er niet altijd evenzeer toe. Financieringsaspecten krijgen bij de toetsing en daarna een eigen plaats. Organisatorische aspecten en gedragsaspecten spelen veelal geen zelfstandige rol, maar het werken aan cultuur en communicatie blijkt belangrijk te zijn.

Dr. W. Westerman is universitair docent financieel management bij de Faculteit Bedrijfskunde van de Rijksuniversiteit Groningen. Hij dankt Dr. J.H. von Eije van dezelfde faculteit en andere leden van de redactie van het MAB voor hun inbreng bij dit artikel. Voor alle nog resterende tekortkomingen is echter uitsluitend hijzelf verantwoordelijk.

\section{Inleiding}

Nederlandse ondernemingen zien zich steeds meer genoodzaakt om te groeien door te investeren in het buitenland. Ook al betreft het daarbij gewoonlijk Europese landen, het gaat toch al gauw om complexe processen. Hierbij is de inbreng van het financieel management bij het investeren onderbelicht. Dit artikel vormt een weergave van mijn promotieonderzoek (Westerman, 2003). De centrale vraag van het onderzoek luidt als volgt: 'Hoe kan het financieel management bij Europese investeringen worden beschreven en welke patronen kunnen in het investeringsproces worden herkend?' Er worden daarbij vier deelvragen onderscheiden:

1 Welke strategische analyses worden bij het Europees investeren gemaakt?

2 Hoe gebeurt bij Europese investeringen de financiële investeringsselectie?

3 Welke rol spelen risico- en financieringsaspecten bij Europese investeringen?

4 Hoe zien bij Europese investeringen organisatie- en gedragaspecten eruit?

De opbouw van dit artikel is als volgt. Eerst wordt in paragraaf 2 de gevolgde methodologie neergelegd. De onderzoeksstrategie, de case-research-methode, wordt onderbouwd en ingevuld. Daarna wordt literatuur over onderwerpen uit de respectievelijke deelvragen besproken. Vervolgens wordt het conceptueel raamwerk neergezet. De paragraaf sluit af met een beschrijving van het onderzoeksobject: Nederlandse directe buitenlandse investeringen in Europa. In paragraaf 3 staat een weergave van het in de jaren 1999 tot en met 2001 bij zeven Nederlandse ondernemingen uitgevoerde praktijkonderzoek. Het gaat hierbij om in Europa ervaren investeerders. Voor elke onderneming 
wordt een korte case-beschrijving gemaakt. In paragraaf 4 worden de resultaten van het praktijkonderzoek vergelijkbaar gemaakt en geanalyseerd naar aspecten van het conceptueel model, waarna er wordt gezocht naar overeenkomsten en verschillen bij de cases. Ten slotte worden in paragraaf 5 de onderzoeksvragen beantwoord, gevolgd door het afrondend opgestelde model van het investeringsproces, alsmede enkele aanbevelingen voor de praktijk en de wetenschap.

\section{Methodologie, theoretische pijlers, concep- tueel model en onderzoeksobject}

Dit onderzoek is grotendeels kwalitatief van aard. Het hart van het onderzoek wordt gevormd door zeven case-studies, die vervolgens zijn geanalyseerd. Het gehanteerde theoretische raamwerk is gebaseerd op vier pijlers: de strategische analyse, de financiële investeringsselectie, de risico- en financieringsaspecten, en de organisatie- en gedragsaspecten. Het conceptueel model brengt al deze aspecten in één kader bijeen. Nederlandse ondernemingen, waaronder de hier onderzochte, investeren vooral in Europa. Op de genoemde onderwerpen wordt nu achtereenvolgens nader ingegaan.

\section{Methodologie}

De onderzoeksstrategie kenmerkt zich door een grotendeels kwalitatieve aanpak. Er zijn op deelaspecten in Nederland al veel kwantitatieve survey's uitgevoerd (onder meer: Herst, Poirters en Spekreijse,1996; Burger, Westerman en Witteveen, 1998). Kwalitatief onderzoek kan daarentegen juist breder en dieper inzicht bieden. Case-research is dan een geschikte methode (Biemans en Van der Meer-Kooistra, 1994a/b). Het onderzoek kan namelijk deels 'real time' plaatsvinden, de afbakening van het onderzoek versus zijn context is variabel, het aantal variabelen kan hoog oplopen en de informatie kan uit meerdere bronnen komen. Case-research kent in principe een drietal onderzoeksfasen, die ook hier zijn gevolgd. Gedurende de voorbereidingsfase is de probleemstelling geformuleerd en in een conceptueel kader geplaatst. Tevens is een proefcasus van een nietEuropese investering uitgewerkt. In de uitvoeringsfase zijn in totaal zeven gevallen onderzocht, met name geleid door persoonlijk contact met een sleutelinformant. In de analysefase is het vooraf ontworpen conceptueel model ingevuld, waarbij naar patronen is gezocht, een nieuw model is ontstaan en adviezen zijn geformuleerd.

\section{Theoretische pijlers}

De literatuur geeft aan de strategische analyse van directe buitenlandse investeringen een plaats door te kijken naar de ontwikkeling van de internationalisering. Deze is te verklaren op grond van kostenverschillen, marktkrachten, of combinaties van deze beide (Porter, 1990). De wijze van internationalisering betreft in de eerste plaats de markttoetreding- en expansiestrategie. Belangrijk is hierbij de keuze tussen enerzijds zelf starten ('greenfield-investering') en anderzijds acquireren van activiteiten. Tevens is de landenportfoliostrategie van belang. Het aantal landen waarop gefocust wordt, de geografische spreiding en de landaantrekkelijkheid doen er hier toe. Verder is er een groot areaal aan concrete investeringsmotieven, zoals beperking van concurrentie en beschikbaar ondernemerschap. Er zijn diverse parallellen tussen de ontwikkeling van de internationalisering en daarbij passende strategisch managementtechnieken te trekken, bijvoorbeeld waar het gaat om groeivraagstukken. Vier strategische scholen - de design school, de planningschool, de positioneringschool en de waardemanagementschool - zijn van belang (Minzberg en Lampel, 1999). Strategische technieken omvatten de welbekende SWOT-analyse, groeimatrices zoals die van de Boston Consulting Group, alsook voorspelmethoden (zoals brainstorming en simulatie) en benchmarking.

Voortbouwend op Tempelaar (1986) kunnen vier visies op financiële investeringsselectie worden onderscheiden: een boekhoudkundige benadering (die winstanalyses voorop stelt), een financiële planningbenadering (gericht op financiële modellering), een financieel-economische benadering (die contante waardemethoden centraal stelt) en de aandeelhouderwaardeanalyse (waarin strategische overwegingen samengaan met alle hiervoor genoemde benaderingen). De financiële investeringsselectie omvat ten eerste de financiële modellering: het raamwerk voor en de manier van omgaan met het hoofdmodel en de submodellen, het in relatie tot de balans bepalen van componenten van de winst en de kasstroom, alsmede de eventuele discontering van deze beide. Ten tweede betreft de financiële investeringsselectie de toegepaste financiële selectiemethoden. Boekhoudkundige methoden omvatten onder meer kengetallen, rendementen op investeringen (ROI's) en terugverdientijden. Voorbeelden van disconteringsmethoden zijn de netto contante waarde (NCW)-methode en de internal rate of return (IRR)-methode. Aandeelhouderwaardemethoden breiden deze methoden ten slotte uit met 
een strategische component (Rappaport, 1986) of met een rapportagevisie (Stewart, 1991).

Ten aanzien van relevante aspecten van financieel risico en financiering van directe buitenlandse investeringen worden hier in navolging van Tempelaar (1986) twee manieren van kijken gebruikt. De institutionele benadering is gericht op omstandigheden en gebruiken. De economisch-theoretische benadering maakt gebruik van de vermogensmarkttheorie (Modigliani en Miller, 1958 en 1963) en de agentschapstheorie (Jensen en Meckling, 1976). Wat betreft de financiële risico's worden in dit onderzoek bedrijfsrisico's, valutarisico's en politieke risico's onderscheiden. Behalve op het onderkennen en beheersen van eventuele financiële risico's is specifiek gelet op de verwerking hiervan bij de financiële investeringsselectie. Wat betreft de financiering is de aandacht algemener van aard gebleven, mede omdat bij directe buitenlandse investeringen de adjusted present value (APV)methode (Shapiro, 1988) in Nederland nog weinig weerklank krijgt ${ }^{1}$. Bij de financiering gaat het om de normen rond vermogensstructuren, de rangorde bij de financieringsmix, de af te tappen vermogenbronnen, de afwikkeling van verplichtingen, de vormgeving van de juridische structuur en de toe te passen fiscale technieken.

Er is een onderscheid tussen organisatorische en gedragsmatige aspecten van het investeren. Bij het organiseren gaat het om de feiten: wie doet wat en hoe? Er is een koppeling met concepten over (investerings)control mogelijk (Simon, 1976; Anthony, Dearden en Govindarajan, 1992). Onder meer budgetterings- en rapportageaspecten van investeringen zijn dus van belang. Tevens is aandacht gerechtvaardigd voor het faseren van werkzaamheden tijdens het proces, het werk van diverse soorten interne en externe functionarissen, alsmede de verdeling van verantwoordelijkheden bij het investeren. Het tweede 'zachte' aspect betreft de gedragingen van investeerders: waarom doen ze iets op een bepaalde manier of laten ze het juist achterwege? De intern gedragstheorie (Cyert en March, 1963), de agentschapstheorie (Jensen en Meckling, 1976) en de 'behavioral finance'-stroming (De Bondt en Thaler, 1994) bieden handreikingen om de rationaliteit van het besluitvormingsproces te belichten. Een veelheid aan aspecten valt hier te onderscheiden: strevingen, oplossingsgerichtheid, representaties, risicohoudingen, timing, omgaan met informatie, opportunisme en reputaties. In aansluiting op het voorgaande is het in figuur 1 neergelegde conceptuele (hoofd)model ontwikkeld.

\section{Onderzoeksobject}

Directe buitenlandse investeringen in Europa gebeuren vooral in de Europese Unie (EU). De ruime geografische spreiding van de cases volgt dit gegeven. De EU kenmerkt zich door de gemeenschappelijke markt, het op groei, vrije markten en concurrentievermogen gerichte beleid en een grote invloed in Centraal- en Zuidoost-Europa (http://europa.eu.int, 2002). Europese harmonisatie van de verslaggeving vergemakkelijkt vooral bij overnames de financiële investeringsselectie. Daarnaast heeft de introductie van de euro gevolgen voor het financieel risicobeheer. Voor de financiering is de liberalisering en deregulering in het Europese bankwezen van belang. De lokale mededinging groeit door harmonisatie van het vennootschapsrecht, preventief toezicht op concentraties en vermindering van fiscale concurrentie. De fusies en overnames door Nederlandse ondernemingen zijn (met een piek in 2000) veel omvangrijker dan de greenfields (Myiake en Sass, 2000; http://www.dnb.nl, 2002). In diverse sectoren is een herstructurering op Europees niveau in werking gezet. In de meeste hiervan zijn er voor Nederlandse investeerders in het veranderende en vergrote Europa aantrekkelijke bedrijfstakken aan te wijzen. In dit onderzoek zijn de gevallen zo regelmatig mogelijk over deze sectoren verspreid, teneinde innovatieve en marktleidende ondernemingen van diverse aard te onderzoeken.

De onderzochte ondernemingen streven naar Europese marktontwikkeling, wat reeds mondiaal werkende ondernemingen als Unilever en Ahold, alsmede primair kosten- en belastinggedreven investeerders uitsluit. Om voor financieel geïnteresseerden interessant te zijn, moeten financiële overwegingen bij de investeringsselectie een zekere rol spelen. Alleen ervaren investeerders, die tussen 1995 en 2000 drie of meer keren in Europa hebben geïnvesteerd, zijn geselecteerd. Er is gestreefd naar een zekere balans tussen greenfields en overnames, die immers verschillen qua snelheid van marktopbouw. Verder is gekeken naar enkele ondernemings- en omgevingskenmerken. Zowel de grootte van de onderneming als de omvang van de investering kunnen het proces beïnvloeden. Hetzelfde geldt voor de scope van de investeerder: het aantal landen waarin tegelijk geïnvesteerd wordt. De relevante financiële functie kan verschillend georganiseerd zijn en bijvoorbeeld zelfs deel uitmaken van een apart staande eenheid. Omdat er regionale verschillen in investeringsstijl kunnen zijn, is ook gelet op de ligging van de hoofdkantoren in het land. Uit diverse bronnen is zo een 'top 40' van investeer- 
Figuur 1. Directe buitenlandse investeringen: een benadering van het proces

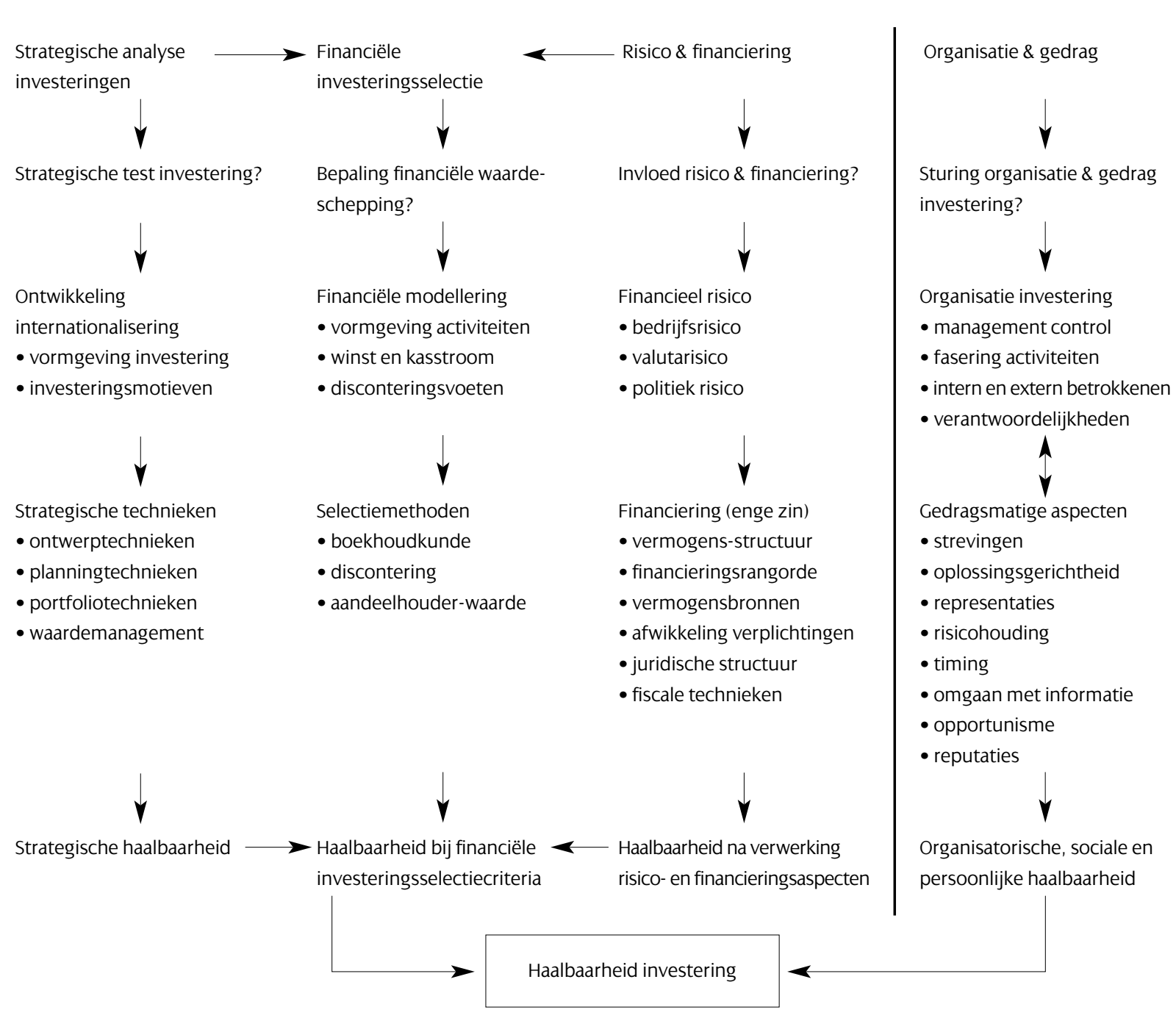

ders samengesteld, waarvan er uiteindelijk zeven zijn geselecteerd. Deze komen hierna aan de orde.

\section{De zeven onderzochte cases}

\section{Koninklijke Numico}

Voor de eerste casus werd er gezocht naar een alom erkend succesverhaal. Deze casus werd aangeleverd door het huidige Koninklijke Numico². De acquisitie van de Milupa-activiteiten van het Duitse Altanaconcern, waardoor het toenmalige Nutricia in 1995 met tweederde werd vergroot, markeerde de ontwikkeling van Numico tot een Pan-Europese speler in kindervoeding. Enkele opvallende elementen bij deze investering betreffen:
1 de grote omvang van de acquisitie, die overleving van Nutricia veilig stelde;

2 het belang dat werd toegekend aan economisch-technische verkenningen;

3 een nauwgezette financiële modellering, toewerkend naar de financiële selectie;

4 het enthousiasme en tempo waarin informeel, maar met duidelijk afgebakende verantwoordelijkheden, doelgericht aan de acquisitie werd gewerkt;

5 het streven naar een goede onderlinge communicatie, vooral met Milupa.

Bovendien valt het op, dat men bij Numico herhaaldelijk culturele factoren aanhaalt. Het cultuurverschil met 'afstandelijke' Duitsers op het hoofdkantoor was 
groot en bleek deels onoverbrugbaar. Op operationeel niveau waren er echter geen grote problemen.

\section{Randstad}

Het uitzendconcern Randstad werd gekozen vanwege haar greenfields, maar ze deed in Europa ook overnames. Alhoewel tijdens het onderzoek vaak in algemene termen is gesproken, is er in de casus vooral gerefereerd aan het opzetten van vestigingen in Italië vanaf 1999 en een grote overname uit 1999 (Time Power) in Duitsland. Enkele opvallende zaken uit deze gevalstudie zijn:

1 Randstads zelf gekozen gidsfunctie en marktgerichte strategische keuzes;

2 de duidelijke voorkeur voor greenfields boven overnames;

3 een gestandaardiseerde financiële modellering (voor zowel greenfields als overnames), geënt op waardemanagementprincipes;

4 vooral bij greenfields is het financiële rekenwerk gericht op het in kaart brengen van eventuele risico's;

5 de open communicatie en het willen leren van fouten uit het verleden.

Het is tevens opvallend aan de benadering van Randstad, dat zeer veel belang wordt gehecht aan een goede marktstrategische analyse.

\section{NNZ Beheer}

NNZ Beheer was een kleinere Groningse onderneming met een goede reputatie, die zich specialiseerde in agrarische verpakkingen. NNZ nam in 1997 de groothandel Kreuz in Duitsland over. Het is tot op heden de grootste overname die ze ooit heeft gedaan. Het betrof echter een land en een bedrijf waar de NNZ Groep al goed mee vertrouwd was. Even later waren er een kleine overname in Italië en een middelgrote acquisitie in Oostenrijk (met een Hongaarse nevenvestiging). Enkele bij NNZ opvallende zaken zijn:

1 de duidelijke strategische keuzes en meervoudige strategische analyses;

2 met financiële modellen worden weliswaar winsten en kasstromen berekend, maar er worden in principe geen verwachte contante waarden bepaald;

3 een geplande grote overname in Duitsland zorgt voor een heroverweging (en later herstructurering) van de financiering van de hele Groep;

4 de nadruk op informatievoorziening, daarbij kennis van derden gebruikend;

5 een persoonlijke benadering van overnames door de directie van NNZ.

Voor verschillen in werkwijzen tussen NNZ en haar fusiepartners verwijst NNZ naar objectieve factoren, zoals de omvang van het bedrijf en de locale regelgeving.

\section{Koninklijke Boskalis Westminster}

Koninklijke Boskalis Westminster kocht het middelgrote Zweedse baggerbedrijf Skanska Dredging in 2000. De mede-regisserende directeur strategie en ontwikkeling bleek bereid om dit toe te lichten. Door de overname werd een nieuw thuisland aan de activiteiten van de baggeraar toegevoegd. Enkele opvallende kenmerken uit de casus zijn:

1 het concept van thuismarkten, die voor schaalvoordelen en stabiliteit zorgen;

2 een van geval en gebruiker afhankelijke, meervoudige en ongecompliceerde, 'going concern' of 'break up' financiële waardering van overnames;

3 het ter voorkoming van te veel betalen soms deels verlaten van DCF-methoden;

4 de nadruk op het afdekken van financiële risico's van overnames met garanties;

5 het belang van een goede structurering en sturing van het acquisitieproces en de hierbij horende besprekingen (zonder angst voor het onderhandelingsspel).

De onderneming bouwt haar leidende positie in de wereldbaggermarkt steeds verder uit. Boskalis denkt zelf de optimale grootte nog niet te hebben bereikt: in het nu nog gesloten deel van de markt zijn nog meer uitbreidingsmogelijkheden.

\section{Bollegraaf Beheer Apppingedam}

Bij Bollegraaf Beheer Apppingedam (een kleine fabrikant van sorteerinstallaties) is vooral de opbouw van een steunpunt in Spanje vanaf 1999 aan de orde gekomen. Deze nieuwe vestiging heeft een aantal unieke kenmerken, maar lijkt verder sterk op de andere in Europa. Opvallende elementen bij deze directe buitenlandse investering betreffen:

1 het geloof dat wordt gehecht aan de marktpotentie van Bollegraaf-installaties;

2 de duidelijk meegegeven doelstellingen, maar informele financiële planning van een nieuwe vestiging;

3 de gestandaardiseerde, risicobeperkende structurering van de investering (de bestuurder krijgt een groot aandeel en er worden diverse contracten gesloten);

4 de aandacht die aan financieringsaspecten in ruime zin wordt geschonken;

5 het aan enthousiast ondernemerschap en wendbaarheid gehechte belang.

Dat internationalisering bij Bollegraaf prioriteit heeft, blijkt ook uit de grote kaarten die in de hal van de 
hoofdvestiging in Appingedam hangen. Hierop is voor de belangrijke landen aangegeven, waar activiteiten zijn of worden uitgevoerd.

\section{Drie Mollen Holding}

Het middelgrote Drie Mollen Holding nam in 2000 de Zwitserse koffiebranderij Rost over. Deze koop past goed in het stramien van regelmatige overnames door de Groep. Enkele uit het onderzoek blijkende opvallende kenmerken uit deze casus zijn:

1 de koppelingen tussen strategie, besturingsfilosofie en bedrijfsactiviteiten;

2 het willen begrijpen van grondslagen van de financiële waarde van overnames;

3 de uitdieping van de financiële modellering en selectiemethoden per situatie;

4 het willen doorgronden en per geval afdekken van financiële risico's;

5 de nadruk op de besturing van de overname met businessplannen waar het locale management voor staat en met regelmatige strategische controles.

Drie Mollen is uitgegroeid tot de grootste private label koffiebrander in Europa. Daarbij wil zij als een onderneming met verscheidene eigenstandige lokale bedrijven worden beschouwd. Het omgaan met deze cultuurverschillen heeft bij koffie te maken met een lokaalgerichte wijze van aansturen, gebaseerd op specifieke kenmerken van elke lokale markt.

\section{Nutreco Groep}

De Nutreco Groep, in 1994 afgesplitst van British Petroleum (maar met een lange historie van enkele van haar belangrijke bedrijven), heeft in 2000 diverse overnames in Europa gepleegd. De onderneming heeft permanente 'mergers en acquistions'-specialisten in dienst. Enkele opvallende kenmerken uit de beschrijving van de casus zijn:

1 een uitdrukkelijk ambitieus groeistreven dat overnames noodzakelijk maakt;

2 het combineren van een nadruk op strategische fit met de eis tot gedegen financieel-administratief gemodelleerde onderbouwing;

3 het primaat van de netto contante waarde-methode bij de investeringsselectie;

4 zowel bedrijfs- als landenrisico's worden financieel gespecificeerd;

5 een gestructureerde aanpak van het overnameproces met acquisitieteams, waarvan de trekkers achteraf op de resultaten worden aangesproken.

Nutreco is mede door de acquisities waarnaar in deze laatste casus meer in het bijzonder is gekeken, uitge- groeid tot een belangrijke Europese (of zelfs wereld-) speler in de voedselproductiekolommen van vis, pluimvee en varkens.

\section{Resultaten en patronen}

Om tot betrouwbare conclusies en passende aanbevelingen te komen, zijn de cases eerst vergeleken op kenmerken van de relevante omgeving en de eigen onderneming. De vergelijking is voortgezet op de gemodelleerde aspecten aangaande strategische analyse, financiële investeringsselectie, risico en financiering, en organisatie en gedrag. Zo zijn er per variabele gewoonlijk twee of drie deelaspecten aan het licht gekomen. De volgende algemene waarnemingen zijn uit de cases af te leiden:

1 ondernemings- en omgevingskenmerken sturen de wijze van investeren mee;

2 de financiële waardecreatie staat bij het toetsen van een investering voorop;

3 de financiële modellering gaat aan de financiële investeringsselectie vooraf;

4 financieringsaspecten krijgen bij de toetsing en daarna een eigen plaats;

5 strategische en organisatorische aspecten zijn kaderstellend voor de waardering;

6 risico- en gedragsaspecten spelen in het hele proces veelal geen zelfstandige rol;

7 de wijze van internationalisering ligt voor het investeren al min of meer vast;

8 investeerders maken in het proces cultuur- en communicatieaspecten expliciet.

Er zijn meer dan veertig overeenkomsten tussen de zeven cases. Bij een klein aantal variabelen uit het conceptueel model zijn geen vermeldenswaardige overeenkomsten gevonden (bijvoorbeeld als het gaat om de toegepaste strategische technieken), terwijl bij een paar andere variabelen zelfs meerdere eensluidende kenmerken zijn aangetroffen. Een tiental overeenkomsten betreffen de ondernemings- en omgevingskenmerken, wat een aanwijzing vormt voor een hoge homogeniteit van de populatie. De ondernemingen zijn ouder dan veertig jaar. Ze zijn multinationals, maar geen transnationals. Ze zijn leidend in de markt en bepalen mede de technologie. Alle investeerders stellen groei en resultaat voorop. Dat werkt zich uit in een prioriteit voor internationalisatie en een streven naar topposities. Onder de centrale organisatie valt een tiental subgroepen. De financiële functie krijgt bij de populatie een centrale plaats naast de andere functies.

Op inhoudelijke aspecten (strategische analyse, finan- 
ciële investeringsselectie, en risico en financiering) zijn er verscheidene overeenkomsten. De ondernemingen doen in Europa zowel greenfields als overnames. In principe bouwen ze hun landenportfolio concentrisch op, geleidelijk aan verder weg van Nederland investerend. Motieven voor investeringen zijn vooral commercieel, waarbij het accent ligt op synergie met de bestaande onderneming. In de gebruikte checklists zijn strategische technieken verwerkt. Winsten en kasstroom worden genormaliseerd naar eigen gebruik en op de lokale situatie toegespitst. Disconteringsvoeten zijn weliswaar geëgaliseerd, maar worden enigszins gediversifieerd per land. Alle ondernemingen passen meer dan één boekhoudkundige methode toe. Contante waardemethoden zijn echter niet algemeen. Een verhoging van het bedrijfsrisico wordt vermeden. Het valutarisico wordt weinig gevoeld. Het operationeel risico wordt acceptabel geacht. Lokale financiering dempt het translatierisico. Landen met een te hoog politiek risico worden gemeden. Vooral traditionele maatstaven bepalen de vermogensstructuur. Ook banken hebben hierop invloed. Financiering gebeurt met eigen en bancair geld. Verplichtingen worden volgens lokale usances afgewikkeld. Binnen- en buitenlandse mogelijkheden tot juridische en fiscale structurering worden netjes gebruikt.

Wat betreft de contextuele aspecten (organisatie en gedrag, inclusief cultuur en communicatie) zijn er veel overeenkomsten. Het eigen managementcontrolsysteem wordt snel en uniform bij het nieuwe bedrijf ingevoerd. De investering gebeurt in drie fasen: idee, ontwerp en uitvoering. Eigen financiële en andere functionarissen doen, onderling sparrend en met behulp van externe accountants en juristen, de financiële beoordeling. De onderneming regisseert daarbij het werk zelf. De interne trekkers zijn aanspreekbaar op de uitkomsten. Financiële kerncompetenties moeten in eigen huis anwezig zijn. De financiële functie heeft echter een secundaire rol. Het gaat bij het investeren om het beste voor de onderneming. Algemeen fatsoen wordt gecombineerd met een 'Hollandse' handelsgeest. Opdeling en coördinatie van taken en instemming met de gang van zaken bewerken oplossingen voor problemen. Tijdens het investeren gaan bij de betrokkenen rationaliteit en beleving gelijk op. Meevoelende omgang en inlevend taalgebruik passen bij het intern en extern samen een traject ingaan. Beperkte risico's van het ondernemen worden aanvaard. Tijdsdruk wordt maar weinig gevoeld. Gebreken aan informatie worden opgeheven. Informatie schept vertrouwen. De investeerders grijpen beheerst hun kansen. Persoonlijke reputaties staan weinig op het spel.
Waar bijna alle gevonden overeenkomsten algemeen geldig zijn, is dat met het hier gevonden vijftigtal verschillen niet het geval. Ongeveer de helft van deze verdienen hier vermelding, omdat ze duidelijk in de populatie aanwijsbaar zijn. Geen één van deze evidente contrasten betreft de strategische analyse, die immers met checklists gebeurt. Wat betreft de financiële investeringsselectie verschilt de diepte en breedte van de modellering (al dan niet volgens een financieel waardemanagementstramien), de doorrekening en weging van financiële gevoeligheden, het werken met voorspeltermijnen en restwaarden, het aanpassen van kasstromen en disconteringsvoeten, het aantal gebruikte selectiemethoden, het belang van boekhoudkundige methoden respectievelijk disconteringsmethoden en de niet-bindende rol van disconteringsmethoden tijdens het investeringsproces. Risico- en financieringsaspecten verschillen rond het significant achten van risico's, het hedgen van valutarisico's, het negatief of positief beleven van politieke risico's, het financieren met (achtergestelde leningen of met) nieuwe aandelen, het ontwerpen van een juridische structuur en de fiscale behandeling van de investering.

Een aantal van de aangetroffen verschillen heeft te maken met aspecten van organisatie en gedrag (inclusief cultuur en communicatie). Qua organisatie gaat het om de manier en mate van structurering van de investering binnen en tussen de fasen, de algemene verdeling van de verantwoordelijkheden, de betrokkenheid van de hoofddirectie in het proces, de rol van de hoogste leidinggevende bij het financieel management van de investering, de aanwezigheid van specifieke fusie- en overnamefunctionarissen en de uitbesteding van de informatieverzameling aan externe specialisten. Verschillen in gedrag betreffen de scherpte van de eigen representaties bij de investeringen, het initiatief tot voortgang van het proces (dat eventueel bij anderen dan de investeerder ligt) en de harde of zachte wijze van uitonderhandelen van de eventuele gerezen geschilpunten.

Op zoek naar patronen bij de Europese investeringen die in dit onderzoek centraal staan, blijken alle aangetroffen overeenkomsten en de evidente verschillen tussen de zeven gevallen op de volgende factoren terug te voeren te zijn:

1 markttoetreding- en expansiestrategieën (greenfields versus overnames);

2 de omvang van de investeerder (klein, middelgroot of groot);

3 de omvang van de investeringen (eveneens klein, middelgroot of groot); 
4 de manier van ondernemingsbesturing (Rijnlands of Angelsaksisch ${ }^{3}$ );

5 de omgang met cultuur en communicatie (professioneel of amateuristisch);

6 de verwerking van regionale verschillen (impliciet versus expliciet).

Anders dan bij de eerste vier factoren het geval is, is er niet expliciet onderzoek gedaan naar de bij de laatste twee factoren ondergebrachte kenmerken. De daarbij genoemde dichotomieën zijn dan ook vooral bedoeld voor de gedachtevorming. De eerste drie factoren blijken ook meer verklarende waarde te hebben dan de laatste drie.

\section{Conclusies en aanbevelingen}

$\mathrm{Nu}$ kan de eindbalans van dit onderzoek naar het financieel management bij Europese investeringen door Nederlandse ondernemingen worden opgemaakt. De vragen bij dit onderzoek gaan over de strategische analyse, de financiële investeringsselectie, de risico- en financieringsaspecten, alsmede de organisatorische en de gedragsmatige aspecten. De manier van internationaliseren ligt voor het investeren al grotendeels vast. Strategische analyses met checklists geven de kaders voor de financiële waardering. Als de financiële modellering uitgebreider en diverser wordt, verschuift tevens het accent van boekhoudkundige naar contante waarde selectiemethoden. Financiële risico's doen er niet altijd evenzeer toe. Financieringsaspecten krijgen bij de toetsing en daarna een eigen plaats. Organisatorische aspecten en gedragsaspecten spelen veelal geen zelfstandige rol, maar werken aan cultuur en communicatie blijkt belangrijk te zijn. Bij het toetsen van een investering gaat het uiteindelijk om de financiële waardecreatie. Het voorgaande kan tot een geïntegreerd model van het financieel managementproces van Europese investeringen leiden. Een dergelijk model faseert aspecten van organisatie, strategie en financiën tijdens het te doorlopen proces (Westerman, 2003). In vier ontwikkelingsfasen gaat het achtereenvolgens om een globale verkenning, de informatieverzameling, de selectie uit voorhanden zijnde alternatieven en de uiteindelijke implementatie.

Uit de eindconclusies komen ten slotte aanbevelingen voort. Het financieel management bij Europese investeringen begint al bij keuzes rond de gang van de internationalisering, die immers patronen van kasstromen en disconteringsvoeten op (middel)lange termijn beïnvloeden. Het begrijpen van achtergron- den is nodig om strategische checklists verder te kunnen ontwikkelen en juist te kunnen toepassen. Het financiële perspectief moet in de waardering al meeklinken. Bij de financiële modellering gaat het daarna om de verdieping van de evaluatie van de investering, qua eigen kracht en qua synergie-effect met de huidige onderneming, in termen van financiële waardeschepping. Passend gebruik van meerdere selectiemethoden, niet per se de moeilijkste overigens, bevordert ten slotte een pluriforme financiële beoordeling. Niet weg te werken financiële risico's (waaronder de bedrijfsrisico's) worden in dit kader meegenomen, evenals de effecten van de financiering op de financiële structuur van de moedermaatschappij en haar nieuwe dochter. Dat zal dan tot aanpassingen in kasstromen en disconteringsvoeten kunnen leiden. Een stevige interne en externe organisatie, alsmede een passend gevoel, hard werken en gezond verstand, moeten het voorgaande mogelijk maken. Wetenschappelijk kan deze aanpak van directe buitenlandse investeringen worden aangevuld met multi- en interdisciplinaire studies, die bijvoorbeeld financiële aspecten verbinden met cultuur en communicatie.

\section{Literatuur}

Anthony, R.N., J. Dearden en V. Govindarajan, (1992), Management Control Systems, zevende druk, Irwin, Homewood, III.

Biemans, W.G. en J. van der Meer-Kooistra, (1994a), Case research voor bedrijfskundig onderzoek 1, in: Bedrijfskunde, jaargang 66, nr. 1, pp. 51-56.

Biemans, W.G. en J. van der Meer-Kooistra, (1994b), Case research voor bedrijfskundig onderzoek 2, in: Bedrijfskunde, jaargang 66, nr. 2, pp. 95104

Booth, L., (2002), Finding Value Where None Exists: Pitfalls in Using Adjusted Present Value, in: Journal of Applied Corporate Finance, Vol. 15, nr. 1, Spring, pp. 95-104.

Burger, E.D.L., W. Westerman en D.M. Witteveen, (1998), De acquisitiestrategie bij de verwerving van overnames door beursgenoteerde ondernemingen, in: Tijdschrift voor Bedrijfsadministratie, jaargang 102, nr. 1218, december, pp. 463-467.

Cyert, R.M. en J.G. March, (1963), A Behavioral Theory of The Firm, tweede druk 1992, Prentice-Hall, Englewood Cliffs, N.J.

De Bondt, W. de en R.H. Thaler, (1994), Financial Decision-Making in Markets and Firms: a Behavioral Perspective, in: Finance, Series of Handbooks in Operations Research and Management Science, Elsevier North-Holland

De Nederlandsche Bank (DNB), (2002), http://www.dnb.nl. Europese Unie, (2002), http://europa.eu.int.

Herst, A.C.C., S.J.E.W. Poirters en J.G.E. Spekreijse, (1996), Capital Budgeting Practices in The Netherlands, Open Universiteit, Heerlen.

Jensen, M.C. en W.H. Meckling, (1976), The Theory of the Firm: Managerial Behavior, Agency Costs and Ownership Structure, in: 
Journal of Financial Economics, Vol. 3, October, pp. 305-360.

Mintzberg, H. en J. Lampel, (1999), Reflecting on the Strategy Process, in: Sloan Management Review, Spring, pp. 21-30.

Modigliani, F. en M.H. Miller, (1958), The Cost of Capital, Corporation Finance, and the Theory of Investment, in: American Economic Review, June, pp. 261-277.

Modigliani, F. en M.H. Miller, (1963), Corporate Income Taxes and the Cost of Capital: a correction on, in: American Economic Review, June, pp. 433-443.

Moerland, P.W., (1996), Financiering en besturing van de beursvennootschap, in: J.H. von Eije en P.J.J.M. van Loon (red.), De Financiële Functie en Ondernemingswaarde, Samsom, Alphen a/d Rijn, pp. 35-59.

Moerland, P.W., (1997), Corporate governance: schakering, reikwijdte en definiëring, in: Maandblad voor Accountancy en Bedrijfseconomie, jaargang 71, nr. 12, december, pp. 657-665.

Myiake, M. en M. Sass, (2000), Recent Trends in Foreign Direct Investment, in: Financial Markets and Trends, No. 76, June, pp. 23-41.

Porter, M.E., (1990), Competitive Advantage of Nations, The Free Press, New York.

Rappaport, A., (1986), Creating Shareholder Value: The New Standard for Business Performance, The Free Press, New York.

Shapiro, A.C., (1988), International Capital Budgeting, in: Joel M. Stern en Donald H. Chew Jr. (red.), New Developments in International Finance, Basil Blackwell, Oxford, pp. 165-179.

Simon, H.A., (1976), Administrative Behavior: A Study of Decision Making Processes in Administrative Organization, derde druk, Macmillan, New York. Stewart, G.B., (1991), The Quest for Value: The EVA Management Guide, HarperBusiness, New York.

Tempelaar, F.M., (1986), Het gezicht van de theorie van de ondernemingsfinanciering, in: Maandblad voor Bedrijfsadministratie en -organisatie, jaargang 90, februari, pp. 30-32.

Westerman, W., (2002), Van Nutricia tot Numico: financiële modellering en financiële selectiemethoden bij een Europese overname, in: Maandblad voor Accountancy en Bedrijfseconomie, jaargang 76, nr. 1/2, januari/februari, pp. 48-53.

Westerman, W., (2003), Hollands Glorie gaat Europees: financieel management bij directe buitenlandse investeringen in Europa (proefschrift), Rijksuniversiteit Groningen.

\section{Noten}

1 Booth (2002) toont aan dat de APV-methode gebrekkig toepasbaar is.

2 Een beschrijving van de financiële investeringsselectie, alsmede de risico- en financieringsaspecten bij deze case is eerder in het MAB verschenen (Westerman, 2002).

3 Het Rijnlandse model van ondernemingsbesturing vertrouwt vooral op consensus, samenwerking en harmonie, terwijl daarentegen het Angelsaksische model competitie, marktwerking en conflicthantering vooropstelt (Moerland, 1996 en 1997). 